\title{
Reinforcement of the Papuan traditional communal rights for the Control of Land and Natural Resources
}

\author{
Alwiyah Sakti Ramdhon Syah Rakia ${ }^{1}$, \\ ${ }^{1}$ Faculty of Law, University of Muhammadiyah Sorong, Sorong, Indonesia. \\ Email : ramdhansyah44@gmail.com
}

\begin{abstract}
The Papuan traditional communal rights for the Control of Land and Natural Resources, are rights granted by legislation with a number of special authorities. This study aims to analyze and provide a conception about Reinforcement of the Papuan traditional communal rights for the Control of Land and Natural Resources. This research method uses the type of normative-juridical legal research, which refers to the legal norms of statutory approach, as well as legal theories and principles as supporters. This research is descriptive-analytical, using qualitative analysis methods. The results of this study indicate that although the regulation of the customary rights of customary law communities in Papua has been enforced for a long time, but there are some fundamental things that need attention. First, there is no enforceable ownership rights over the land by the customary law community or Papuan individual indigenous people to land that has been owned by other individuals or legal entities, since the enactment of Perdasus. Second, the utilization of natural resources together must use business entities, without considering the skills of indigenous peoples in general are relatively low in relation to the format of business entities. Third, the lack of attention to the development of human resources in the utilization of natural resources.
\end{abstract}

Keywords: Customary Law, Customary Law Community, Customary Rights of Papua.

\section{Introduction}

Indonesia is not only known as a maritime country, but also an agrarian country in terms of its geographical structure, which is rich in natural resources. In Article 33 paragraph (3) of the 1945 Constitution of the Republic of Indonesia, it is stated that, "The earth and water and the natural resources contained therein are controlled by the state and used for the greatest prosperity of the people". The substance of Article 33 paragraph (3) of the 1945 Constitution of the Republic of Indonesia is essentially not only to assert Indonesia's sovereignty over its territory, but also as an implementation of the Indonesian state's authority to provide protection to natural resources and also to citizens.

The wealth of the Indonesian nation is also evident in the diversity of Indonesian cultures consisting of various ethnic groups with their respective local wisdom. The existence and position of ethnic groups in Indonesia, whether consisting of law communities or customary law communities, is recognized and protected by their existence, as mentioned in Article 18B paragraph (2), namely, "The State recognizes and respects the units of customary law communities and their traditional rights as long as still alive and in accordance with the development of society and the principles of the Unitary State of the Republic of Indonesia, which is regulated in law ".

One of the existence of ethnic groups in Indonesia is the customary law community of Papua / West Papua, amounting to more than 200 indigenous tribes, which are divided into 7 Indigenous Areas of Papua namely Mamta Region, Saireri Region, Domberai Region, Bomberai Region, Meepago Region, 
Lapago Region and Ha Area Anim. In Article 1 letter p, Law Number 21 Year 2001 jo. Perpu No. 1/2008, as stipulated in Law No. 35/2008 (hereinafter referred to as the Papua Special Autonomy Law), states that indigenous peoples are, "Indigenous Peoples are indigenous Papuans who live in the territory and are bound and subject to certain customs. with a high sense of solidarity among its members ". Furthermore, some specific matters governing the Papuan Indigenous Peoples are further regulated in the Papua Special Regional Regulation (Perdasus Papua).

Basically, the Customary Law Community of Papua in the fulfillment of daily life is obtained from forest and river products, which are considered to be indigenous territories. Control over a certain area is the environment of its citizens which includes the right to use the land and all its contents, referred to as ulayat rights. In Article 43 Paragraph (1) of the Papua Special Autonomy Law, the rights of indigenous Papuans are not only recognized, respected, protected, empowered, but also developed. The development of the rights of indigenous and tribal peoples in Papua and West Papua aims to maintain the existence of indigenous and tribal peoples in Papua and to benefit the welfare of indigenous peoples.

The provisions in the Papua Special Autonomy Law are related to the development of the rights of indigenous Papuan communities within the framework of the special autonomy policy, giving legitimacy to indigenous Papuans in terms of control and management of land and natural resources. However, in practice, several problems are found related to overlapping regulations regarding land tenure and natural resources. On one hand, control is exercised by the state, and on the other hand it is given to indigenous and tribal peoples based on customary rights.

For example, when a customary area is made a conservation area by the state which ultimately diminishes the access of customary law communities in managing customary territories based on customary rights. Sometimes also in a certain customary area a permit to build a building or a company is issued without involving all the relevant indigenous peoples, resulting in a dispute over customary land. This is caused by differences in attitudes and interests relating to land and the use of natural resources, both among fellow indigenous peoples, between indigenous peoples, and between indigenous peoples and the government.

The State of Indonesia in its Constitution as stipulated in Article 18B paragraph (2) expressly respects the existence of indigenous peoples. This means that the existence of indigenous and tribal peoples is not only recognized, but also developed and strengthened. Strengthening Papuan indigenous peoples is very relevant given recent regional controversies that tend to reduce the confidence of indigenous Papuans in protecting the country. Reinforcement of the customary rights of indigenous peoples in Papua is not only because the Indonesian constitution guarantees this, but also aims to strengthen the confidence of the Orang Asli Papua (OAP) in protecting the Indonesian state.

\section{Research Methods}

In this discussion, the type of research used is normative-juridical type of legal research, which refers to the legal norms of statutory approach, as well as legal theories and principles as supporters. This research is descriptive-analytical, using qualitative analysis methods. 


\section{Result and Discussion}

\subsection{Customary Rights of Papua Customary Law Communities on Land}

In Article 43 Paragraph (3) of the Special Autonomy Law of Papua, it is stated that the exercise of customary rights as long as they still exist is carried out by the customary authority of the relevant customary community according to the provisions of the local customary law, with respect to the control of the land of the former communal land rights obtained legally according to the method and based on statutory regulations. The right to control the land includes the customary rights of the customary law community and or the individual rights of the members of the customary law community.

In Article 1 of Papua Perdasus Number 23 Year 2008, what is meant by customary community's customary land rights over land is a partnership right owned by a certain customary law community over a certain area which is the environment of its citizens which includes the right to use the land and all its contents in accordance with statutory regulations. While the individual rights of customary law community members over land, are the individual rights owned by certain customary law community members over a certain area which constitutes their living environment which includes the right to use land and all its contents in accordance with statutory regulations.

The Papua Regional Government is obliged to recognize the existence of customary communities' customary rights and / or the individual rights of indigenous people over land. Recognition of the customary community's customary rights is based on the results of research, which involves several parties, namely:

a. customary law experts;

b. customary institutions / customary elders or customary authorities authorized for customary rights and / or individual rights of citizens of the relevant customary law community;

c. non-governmental organization;

d. officials from the National Land Agency of the Republic of Indonesia;

e. officials from the Legal Section of the Regent / Mayor's Office;

f. officials from forestry and mining agencies; and

g. officials from other relevant agencies.

The results of the study are then reported to the Regent / Mayor and / or Governor for further determination, whether a particular indigenous community in Papua still exists or not.

If based on the stipulation of the Mayor / Regent and / or Governor it is stated that it still exists, then the customary law community and or individual members of the customary law community concerned are authorized to carry out management based on customary rights. The management includes:

a. carry out the management of customary communities' customary rights and or the individual rights of customary community members of land in accordance with customary law in force in the relevant indigenous peoples;

b. holding consultations with third parties outside the customary law community members who need land for various purposes; and

c. transfer some or all of the customary rights to the residents to be controlled by each citizen as an individual right. 
The management of customary communities' customary rights and / or the rights of indigenous people to land, may not conflict with statutory provisions. In addition, Article 9 of Papua Province Perdasus No. 23/2008 states that the authority to manage customary rights of customary communities and / or individual rights of indigenous people over land does not apply to land parcels when the stipulation of this Special Regional Regulation already owned by an individual or legal entity with a right to land in accordance with statutory regulations. As mentioned in Article 8 of Perdasus Number 23 of 2008, the management of customary communities' customary rights and or the individual rights of members of customary communities over land, has a number of authorities to:

a. carry out the management of customary communities' customary rights and or the individual rights of customary community members of land in accordance with customary law in force in the relevant indigenous peoples;

b. holding consultations with third parties outside the customary law community members who need land for various purposes; and

c. give up part or all of the customary rights to the residents to be controlled by each citizen as an individual right.

In relation to third parties outside the customary law community who need land for various interests, as stated in Article 8 paragraph (1) letter b, the relinquishment of some or all of the customary rights of the customary law community and or the individual rights of the customary law community members over the land, carried out with compensation agreed upon together. Customary rights to land can also be lent in part or in whole within a certain period to be managed by another party in the form of a lease, or profit sharing or other mutually agreed forms.

\subsection{Utilization of the Papuan Customary Law Community for Natural Resources}

In Article 64 of the Papua Special Autonomy Law, it is stated that the Government of the Papua Province is obliged to carry out integrated environmental management by taking into account spatial planning, protecting living natural resources, non-living natural resources, artificial resources, conservation of living natural resources and their ecosystems, cultural reserves, and biodiversity and climate change by taking into account the rights of indigenous peoples and to the maximum extent possible for the welfare of the population. This means that the Papua Provincial Government must play an active role in environmental management, including paying attention to the welfare and rights of indigenous peoples in the use of natural resources.

In managing natural resources, both the provincial and district / city governments, are carried out on an ongoing basis in several stages such as planning, implementation, supervision, and evaluation. This is intended to improve the quality of the use of natural resources and respect the rights of indigenous and tribal peoples. Based on Article 10 paragraph (3) of Papua Province Perdasus Number 22 Year 2008, the type of management of natural resources is carried out in accordance with the provisions of the legislation concerning management of natural resources. In addition, the management and utilization of natural resources must be based on the provincial spatial plan and Regency / City spatial plan.

As for the use of natural resources by indigenous and tribal peoples, it is carried out by representing the Customary Authority. Customary authority in Papua Province Perdasus Number 22 Year 2008, is a member of the customary law community who is determined to lead the customary law community in 
conducting social, economic, political, legal and cultural relations with other parties based on the relevant customary law provisions. Furthermore, as stipulated in Article 5 of the Perdasus Papua Province Number 22 Year 2008, the rights of the Customary Authorities are:

a. represent each customary community in conducting legal relations in utilizing and transferring the rights of customary community rights to another party; and

b. make decisions based on the advice and opinions of indigenous and tribal peoples in the use of natural resources.

While the obligations of the Customary Authority based on Article 6 of Perdasus Papua Province Number 22 Year 2008, the obligations of the Customary Authority are:

a. safeguard and maintain the boundaries of customary land areas used for the utilization of natural resources;

b. carry out cooperation agreements in the utilization of natural resources based on the approval of indigenous and tribal peoples; and

c. the agreement as referred to in paragraph (2) is carried out according to the provisions of the relevant customary law and obtains approval from the community members of the customary law community in writing.

Based on Article 12 of Papua Province Perdasus No. 22/2008, indigenous and tribal peoples have the right to use natural resources through business activities in the utilization of natural resources. Natural resource utilization activities can be carried out individually or in groups. The activities of utilizing natural resources carried out by individuals must aim to meet the economic needs of the household in accordance with the relevant adat provisions. Whereas according to Article 13 of the Papua Province Perdasus Number 22 Year 2008, efforts to use natural resources together must form a business entity belonging to the customary law community.

\subsection{Reinforcement of the Customary Rights of the Papuan Customary Community}

The control of land and the use of natural resources by the customary law community of Papua and individual indigenous peoples have indeed been regulated in various laws and regulations. However, there are some basic things that need to be considered so that the existence of indigenous and tribal peoples as outlined in the Indonesian Constitution is not only semantic in value. In a sense, the articles in the Constitution are not only a sweetener for the constitution, but are also implementative. There are several things that need to be considered with regard to the customary rights of indigenous Papuan communities and individual indigenous peoples relating to the rights to customary land, as well as the use of natural resources.

First, it is mentioned in Article 9 of Perdasus Number 23 of 2008, the authority to manage customary rights of customary communities and / or the rights of customary community members of land, does not apply to parcels of land which at the time of the stipulation of Perdasus, already owned by individuals or legal entities with a right to land in accordance with statutory regulations. This provision has the potential to harm individual indigenous people, when the individual indigenous people are not inhabiting the land under their control for some time before the Perdasus is established, then back again after the Perdasus is established. Even more so if the land is considered as abandoned land when the right 
owner does not inhabit the customary land. So far there has not been a Perdasus that regulates legal protection related to the return of land rights of indigenous peoples who are considered abandoned because they have not been occupied for a while.

Secondly, based on Article 13 paragraph (1) of Papua Province Perdasus Number 22 of 2008, the activities of utilizing natural resources together must be carried out by forming a business entity belonging to the customary law community, the type of which is adjusted to the laws and regulations. This means that there is only one option for indigenous and tribal peoples in the use of natural resources, namely through business entities. This provision tends not to pay attention to the ability of the legal community regarding business entities which are relatively low. Indigenous peoples in general in their social lives regulate all their needs depending on certain traditions that are generally different from the format of business entities in general.

Third, in the control of land rights and the use of natural resources as stipulated in the legislation, customary law communities and indigenous peoples as individuals tend to be seen as objects, not as subjects. This means that the legal relationship with the customary law community and individual indigenous people is solely because it involves land and natural resources. Meanwhile, the development of human resources to be more proactive is relatively lacking.

It should be remembered that the Papua Special Autonomy Law was created with the aim of giving special authority, not only in terms of government, but also in the service and development of human resources and their interests in Papua and West Papua. Papuan indigenous people must be seen as a community or as a legal subject with all its specificities. Reinforcement needs to be done so that the customary law community and individual indigenous people develop in terms of welfare and sovereignty over their customary territories. In addition, this also supports the decentralization of regional administrations in Papua and West Papua, which has been granted special authority to run effectively.

In relation to strengthening the Papuan customary law community and Papuan indigenous people, there are a number of things that can be done. First, the individual rights of indigenous and tribal peoples to land that are not valid when stipulated by Perdasus and have been owned by an individual or legal entity with some land rights, can be reviewed. If the proof from the indigenous people can prove that the land that has been occupied by other legal subjects is his property, then the land must be returned to its owner. The procedure for returning land owned by indigenous peoples who have proven ownership can be strengthened through the Decree of the Mayor / Regent and the Governor or the court's decision.

Second, the provisions regarding the use of natural resources together by customary law communities which can only be done through business entities, must be strengthened with assistance on understanding business entities, which are carried out by the government on an ongoing basis. This is necessary so that indigenous and tribal peoples can become credible and accountable partners in the use of natural resources. Third, Papuan customary law communities and indigenous peoples must be positioned as subjects. In other words, both the indigenous and tribal peoples and individual indigenous peoples must become "masters in their own country". This relates to the conditions and special authority of the Papua region which is given legitimacy by laws and regulations. The legal relationship that is built with Papuan customary communities and Papuan individual indigenous peoples must pay attention to the social conditions and traditions that are preserved in Papuan customary culture. 


\section{Conclusions}

As an area that has been granted special authority by law, the main goal expected is that every aspect of development in Papua can be developed in accordance with the development and needs of the times. From the description above it can be concluded that there are a number of things that hamper the existence and development of the customary law community in Papua. In terms of regulations, some of the provisions in the Perdasus should be revised so that they can adjust to the times. An effort in the form of reinforcement the customary rights of the customary law community of Papua is very much needed, bearing in mind the Papuan people's trust in the country that has declined.

\section{Reference}

Suharyo. 2019. Legal Protection of Customary Land in Papua in the Welfare State. Rechtsvinding Journal: National Law Development Media. Vol 8 No 3. Jakarta: BPHN.

Bauw. Lily Sugiono. Bambang. 2009. Setting the Rights of Indigenous and Tribal Peoples in Papua in Utilizing Natural Resources. Constitutional Journal: Center for Constitutional Studies at the Faculty of Law, University of Cendrawasih. Vol 1 No 1. Jayapura: Faculty of Law, University of Cendrawasih.

Citrawan. Harison. 2015. The Problem of the Right to Self-Determination: Unraveling the Relationship Between Regulation and Conflict of Natural Resources in Papua. Rechtsvinding Journal: National Law Development Media. Vol 4 No 2. Jakarta: BPHN.

Efendi. 2017. The Authority of Natural Resource Management in a Special Autonomy Frame in Papua. Kanun : Journal of Legal Studies. Vol 19 No 1. Banda Aceh: Faculty of Law, Syiah Kuala University.

Syafa'at. Rachmad. 2011. Political Law and the Rights of Indigenous Peoples Against Natural Resource Access. Legal Horizon Journal. Vol 6 No 2. Yogyakarta: Faculty of Law University of Proclamation 45.

Yoatili Ritta 2015. Implementation of Perdasus Law Politics Number 23 Year 2008 Concerning the Customary Rights of the Customary Law Community of Papua in National Land Law. Repetorium Journal third edition.

The 1945 Constitution of the Republic of Indonesia

Law Number 35 Year 2008

Papua Province Special Regulation Number 22 Year 2008

Papua Province Special Regulation Number 23 Year 2008 